\title{
THE BIRDS OF BARBUDA, WITH NOTES ON THEIR ECO- NOIMIC IMPORTANCE, AND RELATIONSHIP TO THE PUERTO RICAN AVIFAUNA
}

\author{
By Stuart T. Danforth, \\ Professor of Zoölogy and Entomology, College of Agrieulture and Mechanic Arts, \\ University of Puerto Rico.
}

Barbuda is a low coral island surrounded by dangerous reefs situated twenty-five miles due north of Antigua in the northern part of the Lesser Antilles. It has an area of 62 square miles. The island is very flat, most of it being scarcely twenty feet above the sea, and so level that in order to drive teams (or automobiles, if there were any on the island) all that is necessary is to clear away sufficient brush. In the eastern part of the island there are some low limestone hills known as The Highlands, the highest point of which attains an elevation of 205 feet. In the western part of the island is an enormous shallow salt lagoon known as the Salt Pond, or the Lagoon, with an outlet to the sea at its northern end, and bounded on the west by a narrow strip of land. The island's only village, Codrington (in which all of its 903 inhabitants are obliged by law to live) is situated on the shore of the southeastern part of this lagoon. Small sailing vessels proceed directly to the village, but larger craft have to anchor at a considerable distance off the landing known as The River on the south coast of the island, three and a half miles from Codrington.

The climate of the island is dry, and there is no fresh water on the surface, although this is easily obtained from wells. Xerophytic brush occurs everywhere, this being generally very dense in the northern part of the island and of a more open nature in the southern part. Mangrove swamps occur along the coast.

From 1691 until 1870 Barbuda was leased by the British Crown to the Codrington family, who used it as a stock farm for their estates in Antigua and also as a shooting estate. Afterwards other leases were granted, but in 1898 the Crown resumed possession and the island passed under the government of Antigua. The Codringtons introduced deer and guinea fowl. Remnants of these still survive. Land tortoises are abundant in the southern part of the island. A living immature specimen sent to Dr. Thomas Barbour was identified as Testudo tabulata Walbaum. It may have been introduced. 
Comparatively few ornithologists have visited Barbuda, probably due in part to the lack of transportation facilities.

The first ornithological collections on Barbuda were made by Count Dalmas who visited the island in 1875 on a yachting cruise on which he also visited the Canary Islands, various islands of the Antilles, the coast of Venezuela, and the west coast of Africa. Apparently no complete account of his collections, which went to the Paris Museum, has been published, but E. Oustalet (Bulletin de la Société Zoologique de France, Vol. 20, 1895, p. 184) described Loxigilla Chazaliei from two specimens which Dalmas collected on Barbuda February 25, 1875.

The next collections were made in the late summer of 1877 by F. A. Ober for the Smithsonian Institution. George N. Lawrence reported on this collection (Proceedings of the U. S. National $\mathrm{Mu}-$ seum, I, 1878, pp. 232-242). He lists 39 species from Barbuda, but by no means all of these were collected, and some were recorded on very doubtful hearsay evidence only.

In the late summer and fall of $1903 \mathrm{H}$. G. Selwyn Branch spent considerable time collecting on Barbuda, and obtained 158 birdskins there. These were later obtained by the U. S. National Museum, and reported upon by J. H. Riley (Smithsonian Miscellaneous Collections, Quarterly Issue, II, 1905, pp. 277-291).

In the early part of January, 1930, James Bond, collecting for the Academy of Natural Sciences of Philadelphia, spent a few days on Barbuda, but to date has published no account of his collections, with the exception of a few notes on Dendroica subita which were published in the Proceedings of the Academy of Natural Sciences of Philadelphia, Vol. 82, 1930, p. 334.

The present writer, accompanied by an assistant, Virgilio Biaggi, Jr., spent three days collecting on Barbuda in August 1933. We sailed from Antigua at 3 A.M. on August 13 on the S.S. "Saint Raphael" which had been specially chartered to take a party of French sportsmen from Martinique on a hunting trip to Barbuda, as guests of these gentlemen. We arrived at "The River", Barbuda, four hours later. Landing on the sandy beach was accomplished in three stages, first by a motorboat until the water became too shallow, then by a rowboat, and the last part of the way by wading. Mr. Carlton Moore, the warden of Barbuda, was awaiting us with a team of horses for transportation to the village. On arrival there we immediately began collecting, and continued at that occupation until the evening of August 15, when we returned to the "Saint 
Raphael", which sailed that night for Antigua. During these three days we visited the brushy country north and south of Codrington, the salt lagoon and its bordering mangrove swamps, and made an extended trip on foot to the Highlands, ascending to the highest point of land on the island. Observations were made on 33 species of birds, of which 11 were collected.

An examination of the literature available shows that before the time of the writer's visit 47 species of birds had been positively recorded from the island, and 9 additional species doubtfully listed. Seven species are here definitely recorded for the first time, including two which had previously been listed questionably, bringing the list up to 54 species known to occur in Barbuda. The 7 species which have been listed doubtfully are here treated hypothetically, and in the list which follows are enclosed in brackets.

Thirty-six of the fifty-four birds positively known from Barbuda are even subspecifically identical with birds found in Puerto Rico. Of the remaining eighteen species, eight are only subspecifically distinct from forms found in Puerto Rico, and seven more represent genera found likewise in Puerto Rico, leaving only four genera found in Barbuda which are not also found in Puerto Rico. Therefore a study of the birds of Barbuda, including their economic importance, gives us a good insight into our own avifauna.

It is of special interest to note the relationships of Dendroica subita of Barbuda to D. adelaidae of Puerto Rico. These two species, together with $D$. delicata of St. Lucia, constitute what German ornithologists term a formenkreis, a group of closely related species within a genus. The distribution of this formenkreis is most remarkable in being so disconnected on three widely separated islands, with no representation of the group occurring on intervening islands. The appearance of these birds is so similar that they have been regarded by some authorities as only subspecifically distinct, but due to interruptions in the distribution of the group it seems best to regard the forms as distinct species within a formenkreis. Their habits are very similar, except that $D$. adelaidae and $D$. subita prefer dry brushy regions, whereas $D$. delicata of St. Lucia, due to the generally humid nature of that island, is obliged to adapt itself to wetter conditions. The songs of the three forms are quite distinet, which is an additional reason for regarding them as distinct species.

The writer is greatly indebted to the French sportmen, and especially to their representative in Antigua, Mr. Alex. A. Camacho, who made the trip to Barbuda possible; and to Mr. Carlton Moore, the 
warden of Barbuda, and Mrs. Moore, for hospitality and assistance in many ways while on the island.

An annotated list of the birds known to occur on Barbuda follows. The specimens collected by the writer are in his private collection, which is at present deposited at the College of Agriculture and Mechanic Arts of the University of Puerto Rico.

[Podilymbus podiceps antillarum Bangs. Antillean Grebe. "Diver'". Recorded doubtfully by Ober.]

1. Phaëthon lepturus catesbyi Brandt. Yellow-billed Tropic Bird. Found by Ober breeding in cliffs in the eastern part of the island.

2. Pelecanus occidentalis occidentalis Linnaeus. Brown Pelican. Ober states that it breeds.

3. Fregata magnificens rothschildi Mathews. Man-o-war Bird. "Scissor-tail". A common resident. Ober states that it lays in June, and that he found young still in the nest at the time of his visit. In August 1933 the species was common. On one occasion as many as eight were seen together.

4. Ardea herodias herodias Linnaeus. Great Blue Heron. Ober states that it is migratory, arriving about the first of September.

[Casmerodius albus egretta (Gmelin). Egret. Recorded doubtfully by Ober on hearsay evidence.]

5. Leucophoyx thula thula (Molina). Snowy Egret. Branch collected a male on September 22, 1903.

6. Florida caerulea caerulescens (Latham). Southern Little Blue: Heron. Common resident. In 1933 individuals in both blue and white plumages were seen in various localities.

7. Butorides virescens maculatus (Boddaert). West Indian Green Heron. Common resident. A number were seen near Codrington on August 13 and 15, 1933.

8. Nyctanassa violacea violacea (Linnaeus). Yellow-crowned Night Heron. In 1903 Branch obtained two specimens on Barbuda. On August 13, 1932, we observed an adult along the east shore of the lagoon.

9. Dendrocygna arborea (Linnaeus). West Indian Tree Duck. "Whistler". Branch obtained a male on November 16, 1903. The bird which was recorded by Lawrence under the name of Clangula glaucion is possibly this species, as he also refers to it as the "Whistler', a name by which the Tree Duck is known locally.

10. Dafila bahamensis bahamensis Linnaeus. Bahama Duck. "White-throat Duck". Recorded by Lawrence and Riley. 
[Falco peregrinus anatum Bonaparte. Duck Hawk. Recorded by Ober on hearsay evidence.]

11. Falco sparverius caribaearum Gmelin. Lesser Antillean Sparrow Hawk. "Killi-killi". Recorded as very common by Lawrence, and Branch obtained 6 specimens. In 1933 just three specimens were seen. On August 14 one was found dead by a road northeast of Codrington, and a female, apparently its mate, was collected a few feet beyond. Its stomach contained two Anolis lizards about two inches long. Another bird was seen the next day two miles south of Codrington.

12. Numida galaeata Pallas. Guinea Hen. Said to have been introduced by the Codringtons many years ago, but reputed to have become rather scarce in recent years and found only in the woods at a considerable distance from the town. The French sportsmen obtained a few in their bags, and others were served as food at the Government House during our stay.

13. Rallus longirostris manglecola Danforth (?). Clapper Rail. A Rallus recorded by Ober as resident but not common might prove to be this form if specimens could be collected. Special efforts were made in 1933 to obtain this bird, but although some likely mangrove swamps were visited none were seen or heard.

14. Gallinula chloropus portoricensis Danforth. Antillean Gallinule. Branch obtained three specimens in 1903.

[Fulica caribaea Ridgway. Caribbean Coot. Coots were listed questionably by Lawrence as migrants.]

[Charadrius hiaticula semipalmatus Bonaparte. Semipalmated Plover. Listed questionably by Lawrence.]

15. Pluvialis dominica dominica (Müller). Golden Plover. In Ober's day these birds arrived "in immense flocks first storm (N. W.: after Sept. 1st". Branch obtained a male September 2, 1903. In recent years Golden Plovers appear to be scarcer throughout the West Indies.

16. Arenaria interpres morinella (Linnaeus). Ruddy Turnstone Ten birds observed by the writer near Codrington on August 15, 1933, apparently constitute the first record for the island.

[Capella delicata (Ord). Wilson's Snipe. Recorded by Ober on hearsay evidence.]

17. Numenius phaeopus hudsonicus Latham. Hudsonian Curlew. Stated by Ober to be common and breeding, although this last statement must be accepted as doubtful. Branch collected females on September 25 and November 12, 1903. On August 13, 1933, the 
writer noted a flock of four in a mangrove swamp near the southern end of the lagoon, but they were so shy it proved impossible to collect any.

18. Actitis macularia (Linnaeus). Spotted Sandpiper. Strangely enough this ubiquitous species does not seem to have been recorded from Barbuda until now. On August 13, 1933, ten were observed on the east shore of the lagoon, and six on August 15 .

19. Tringa solitaria solitaria Wilson. Solitary Sandpiper. Recorded doubtfully by Lawrence. The first definite record is of one observed by the writer at a stock-watering hole near Codrington on August 14, 1933.

20. Tringa flavipes (Gmelin). Lesser Yellowlegs. Listed by Lawrence as "Common; resident or nearly so". Examples were noted by the writer on August 13, 14 and 15, 1933.

21. Catoptrophorus semipalmatus semipalmatus (Gmelin). Recorded by Ober as common.

22. Erotia melanotos (Vieillot). Pectoral Sandpiper. Branch collected a male on September 22, 1903.

23. Erolia fuscicollis (Vieillot). White-rumped $\mathrm{S}$ an d p i per. Branch collected females on September 20 and 22, 1903.

24. Erolia minutilla (Vieillot). Least Sandpiper. About 40 observed near Codrington on August 13, 1933, and 20 on the 15th. Not previously recorded.

25. Ereunetes pusillus (Linnaeus). Semipalmated Sandpiper. Recorded by Lawrence and Riley.

26. Himantopus himantopus mexicanus (Müller). Black-necked Stilt. Reported by Ober, who said it was not common.

27. Larus atricilla Linnaeus. Laughing Gull. Stated by Ober to breed, but he gives no evidence for the statement. In August, 1933 the species was observed commonly along the coast.

28. Sterna hirundo hirundo Linnaeus. Common Tern. Branch collected a female September 24, 1903.

29. Thalasseus maximus maximus (Boddaert). Royal Tern. Recorded doubtfully by Lawrence. One was observed by the writer at "The River" August 13, 1933.

30. Columba leucocephala Linnaeus. White-crowned Pigeon. "White-head Pigeon". Common resident, recorded by both Lawrence and Riley. In August 1933 the species was found to be fairly common, especially at the Highlands. The French sportsmen had a few in their bags, and secured about a dozen half-grown young alive, which they took back to Martinique in cages. 
31. Columba squamosa Bonnaterre. Scaled Pigeon. One was noted in the day's bag of the French sportmen on August 15, 1933. This apparently constitutes the first record for the island.

32. Zenaida aurita aurita (Temminck and Knip). Zenaida Dove. "Turtle Dove". Abundant and generally distributed. During their three days of hunting in August 1933 the French sportsmen shot over 6,000 of them. In addition they captured nearly 100 living young not yet able to fly which they took back to Martinique in cages. One was collected by the writer on August 15.

33. Columbigallina passerina nigrirostris Danforth. Ground Dove. Abundant resident. A female was collected August 13, 1933.

34. Oreopeleia mystacea mystacea (Temminck). Bridled Quail Dove. Cory (Cat. West Ind. Birds, 1892, p. 97) lists the species from Barbuda.

35. Coccyzus minor rileyi Ridgway. Antigua Mangrove Cuckoo. Recorded by Ober as not common. Branch collected five specimens. In 1933 the writer collected a female south of Codrington on August 15. No other examples of the species were seen. Its stomach contained three large Otiorhynchid weevils.

36. Coccyzus americanus americanus (Linnaeus). Yellow-billed Cuckoo. Listed from Barbuda by Cory (Cat. West Ind. Birds, 1892, p. 102). Probably occurs as a straggler.

37. Orthorhynchus exilis exilis (Gmelin). Crested Hummer. Common resident. In 1933 two were seen at Codrington on August 13 and six at Highlands the next day.

38. Sericotes holosericeus holosericeus (Linnaeus). Blue-breasted Hummer. Common resident. Three were seen at Codrington August 13, 1933, and eight at Highlands the next day.

[Eulampis jugularis (Linnaeus). Red-throated Hummer. Listed from Barbuda by Ridgway (U. S. National Museum Bulletin 50, 1911, p. 478), the authority eited being Lawrence (Proc. U. S. Nat. Museum, 1878, p. 240). On investigation of this reference no citation of the species by name is found, but under Orthorhynchus exilis occurs the following statement, quoted from Ober's notes : " . . Rev. Mr. Curley (one of the proprietors) described a larger species visiting the island later, resembling exactly (he said) the Mango, of which he had a colored plate." As this evidence is so indefinite the species is relegated to the hypothetical list.]

39. Megaceryle alcyon alcyon (Linnaeus). Belted Kingfisher. Migrant from North America, probably common in winter. Branch collected specimens on August 17 and November 19, 1903. 
40. Tyrannus dominicensis vorax (Vieillot). Large-billed Kingbird. "Loggerhead". Common resident.

41. Myiarchus oberi berlepschii Cory. St. Kitts Flycatcher. Recorded by Ober as found infrequently in the thick laurel scrub. Branch collected nine in 1903. In 1933 the species was found sparingly distributed in the dense xerophytic scrub, one being seen south of Codrington on August 13; four, of which a male and two females were collected, at Highlands on August 14; and two northeast of Codrington the same day. The measurements of the male collected are: Wing 82.0 ; tail 80.2 ; culmen from base 25.1 ; tarsus 22.3 millimeters. The two females measure: Wing 82.7-87.3; tail 85.183.3; culmen from base 26.0-26.1; tarsus 23.4-23.3 millimeters. The three birds collected had eaten 81.6 per cent of animal matter and 18.4 per cent of vegetable material. One stomach contained 6 Otiorhynchid weevils (Lachnopus sp.), a small Lepidopterous larva, and 12 seeds of Solanum bahamensis. Another had a land snail, 9 Geometrid larvae, a large Otiorhynchid weevil, a large leguminous seed, and 11 seeds of Solanum bahamensis. The third contained a large Otiorhynchid weevil, some unidentified insect fragments, and some pieces of seeds.

42. Margarops fuscatus fuscatus (Vieillot). Pearly-eyed Thrasher. "Thrush". Branch collected five specimens in 1903. In 1933 the writer observed five at Highlands on August 14.

43. Allenia apicalis (Hartlaub). Scaly-breasted $\mathrm{Thr}$ asher. "Thrush". In 1903 Branch obtained three specimens. On August 14, 1933, the writer observed three at Highlands.

44. Cinclocerthia ruficauda pavida Ridgway. St. Kitts Trembler. "Thrush". Apparently very scarce, the only records being of Ober. In 1933 special search was made for this bird to no avail.

45. Vireo calidris barbadensis Ridgway. Barbados Vireo. Common; breeds. Many observed in August 1933.

46. Coereba dominicana (Taylor). Dominica Honey Creeper. "Yellow-throat". Common resident. A male was collected August 14, 1933, at Highlands. Its stomach contained fragments of insects.

47. Dendroica petechia bartholemica (Sundevall). Golden Warbler. "West Indian Canary". Common resident, found both in the mangroves and throughout the xerophytic brush. On August 14, 1933, several females were noted feeding young on the wing. Three males were collected, one at the edge of the lagoon August 13, another at Highlands August 14. and the third south of Codrington August 15. Two stomachs contained nothing but insect material, among 
which two Syrphid flies (Mesogramma sp.) and a Lepidopterous larva were recognized in one, and five Lepidopterous larvae, an ant pupa, and fragments of Coleoptera, including Chrysomelidae, in the other.

48. Dendroica subita Riley. Barbuda Warbler. "Christmas Bird". This warbler, the only bird peculiar to Barbuda, with the possible exception of the Loxigilla), is closely related to $D$. adelaidae of Puerto Rico, and D. subita of St. Lucia. According to Bond its song is intermediate between the songs of these two forms. It is very common in Barbuda, particularly in the more open brushy country south of Codrington. In this region, where the vegetation consisted of an almost pure stand of shrubs which Dr. N. L. Britton has identified as Volkameria aculeata L., this warbler was absolutely the most abundant bird. It was much less common in the denser mixed scrub of the northern part of the island. Only a few were singing at the time of my visit; the song was a sort of warbling without the characteristic trill of the song of $D$. adelaidae; in fact the song suggested that of $D$. aestiva more than that of $D$. adelaidae. Eight specimens were collected on August 13, 14 and 15, 1933, seven of them south of Codrington and one at Highlands. On August 13 an old nest which appeared to be of this species was found; it was a cup-shaped structure of grasses and other plant fibers placed about five feet above the ground in a Volkameria bush. Three stomachs contained 96.6 per cent of animal matter and 3.4 per cent of vegetable material. Lepidopterous larvae were found in all the stomachs and constituted 64.6 per cent of the food. Diptera, a Pyralid moth, and Coleoptera (including a small Bostrichid beetle and two Cryptocephaline fleabeetles) were also recognized. The vegetable material consisted of some fragments of grass in on stomach and two small seeds in another.

49. Dendroica discolor discolor (Vieillot). Prairie Warbler. Migrant from North America. Branch collected specimens on November 2 and 23, 1903.

50. Setophaga ruticilla (Linnaeus) American Redstart. Winter migrant. Branch collected seven specimens between August 10 and November 23, 1903.

51. Holoquiscalus fortirostris fortirostris (Lawrence). Barbados Grackle. "Blackbird". Introduced from Barbados, according to Mr. Carlton Moore, warden of Barbuda, in the period between 1912 and 1914. Now the species is common in the vicinity of the village of Codrington, but was not observed elsewhere. As many as 150 were 
seen in one flock shortly before dusk on August 14, 1933. On that, date a male was collected. It is definitely fortirostris, and all the other birds seen appeared to be of that form also, as very little difference in color could be noted between different individuals in. the flocks, and all appeared to be of small size. The wing of the male collected measures 104.7 millimeters. In this connection it might be mentioned that all specimens noted in Antigua in July and August of the same year also appeared to be typical fortirostris and a pair collected were definitely so. The wing of the male measures. 103.8 and of the female 91.2 millimeters. The stomach of the bird collected on Barbuda contained 30 large black seeds and fragments. of a beetle.

52. Tanagra flavifrons flavifrons (Sparrmann). Lesser Antillean Euphonia. Apparently very rare. The only record is of a male collected by Branch in 1903.

53. Loxigilla noctis chazaliei Oustalet. Barbuda Bullfinch. "Sparrow". Common resident. The first record is of two collected on February 25, 1875 by Dalmas, which were used by Oustalet in describing Loxigilla Chazaliei as a new form, which has been generally forgotten by ornithologists. However, I am constrained to revive this name at least temporarily until a fuller investigation can be made into the relationships of the various forms of $L$. noctis, due to the evident difference between the bullfinches of Barbuda and Antigua. Those of Barbuda are much grayer in color, a difference that is even more noticeable in the field than with the bird in the hand. Males were collected on the east shore of the lagoon August 13 and at Highlands August 14, 1933. A stomach contained nothing but fragments of seeds.

54. Tiaris bicolor omissa Jardine. Carib Grassquit. "Grassbird". Abundant resident. Males were collected at Highlands August 14 and south of Codrington August 15, 1933. Their stomachs were filled with small seeds. 